Jurnal Pengajian Melayu - JOMAS, Jilid 31, 2020: 133-150

\title{
DIGITISED IDENTITY OF MALAY LANGUAGE LEARNERS AT THE TERTIARY LEVEL
}

\author{
(IDENTITI DIGITAL PELAJAR BAHASA MELAYU \\ PADA PERINGKAT PENGAJIAN TINGGI)
}

\author{
Jyh Wee Sew \\ Centre for Language Studies, Faculty of Arts \& Social Sciences \\ National University of Singapore \\ Singapore \\ clssjw@nus.edu.sg
}

Received: 2 January 2020; Accepted: 9 November 2020

\begin{abstract}
The digitised format is the current norm in the pedagogy of foreign language. There is much interest in the symbolic transactions underlining the development of semiotic identity in blogbased foreign language literacy. This discussion assumed that blogging is an expression of oneself online, thus the content of the blog posts is construable as the make-up of a digitised identity of the learner. Based on a review of existing studies that examined identity development in the form of a textual self, this discussion introduced the notion of digitised identity that arose from computer-mediated communication. The approach to trace digitised identity involved scrutiny of blog posts assigned to the foreign language learners for journaling Malay language learning at the tertiary level. Observing the digitised styling as shown by Malay language learners' managing of online content in their blogs offers some interesting pointers towards an understanding of a digitised identity of the immaterial self. Based on the design and presentation of the blog entries among selected Malay language learners, this study observed a change from ritualistic blogging to an online language display. The use of multiple semiotic assortments, which are reflective of the foreign language learners' stance, is indicative of a digitised expression of self. The observation identified a potential area of e-learning awaiting exploits in the pedagogy of Malay as a foreign language.
\end{abstract}

Key words: Asynchronous learning; blogging Malay literacy; e-learning; foreign language education; digitised identity.

\begin{abstract}
Abstrak
Format digital merupakan norma mutakhir dalam pedagogi pendidikan bahasa asing. Banyak perhatian tertumpu pada pertukaran maklumat simbolikyang kini mendasari perkembangan identiti semiotik dalam literasi bahasa asing yang berpandukan blog. Perbincangan ini mengandaikan bahawa pemaparan blog sebagai suatu ragam pernyataan diri dalam talian, oleh itu kandungan e ISSN 2735 - 1904

https://doi.org/10.22452/JOMAS.vol31no1.9


blog boleh ditafsirkan sebagai satu paparan identiti digital seseorang pelajar. Berdasarkan tinjauan kajian yang sedia ada tentang perkembangan identiti bersifat keperibadian tekstual, perbincangan ini memperkenalkan fahaman identiti digital yang wujud daripada komunikasi berantara komputer. Pendekatan yang digunakan untuk mengesan identiti digital melibatkan penelitian paparan blog yang ditugaskan kepada pelajar bahasa asing untuk mencatatkan pembelajaran bahasa Melayu pada peringkat pengajian tinggi. Pengamatan gaya digital sebagaimana yang ditunjukkan oleh pelajar-pelajar bahasa Melayu semasa menguruskan kandungan blog dalam talian mereka memperlihatkan beberapa penunjuk menarik ke arah pemahaman identiti semiotik di sebalik jati diri niskala. Berdasarkan reka bentuk dan pembentangan dalam kiriman blog pelajar bahasa Melayu yang terpilih, kajian ini mendapati perubahan daripada aktiviti memblog yang bersifat ritual bertukar ke gaya persembahan bahasa dalam talian. Penggunaan kepelbagaian semiotik, yang beraneka rupa dalam pemaparan sudut pandangan beberapa orang pelajar bahasa asing, mendedahkan pernyataan jati diri yang bersifat digital. Pengamatan ini mengenal pasti suatu bidang e-pembelajaran yang berpotensi ternantikan tinjau-selidik dalam pedagogi bahasa Melayu sebagai bahasa asing.

Kata Kunci: pembelajaran tidak segerak; memblog literasi Melayu; e-pembelajaran; pendidikan bahasa asing; identiti digital.

\section{Introduction}

There are many manifestations of self, including real or basic self, and emergent or social self (Cutler, 1996; Lam, 2000; Sawyer, 2001). In the Asian perspective, the boundary of both real and emergent self is not a distinctive one. Social psychology experts, Chang, Osman, Tong, and Tan (2011), for example, report that Chinese and Malays exhibit and place great importance on the interdependent self, or the big SELF rather than the individualistic persona, or the small self. The concept of separated selves has been identified in the digitised exchanges of a Chinese immigrant speaker of English. He has been displaying different gender roles online that were relatable to rhetorical, and biographical identities, respectively (Lam, 2000). The relevance of displaying multiple simulated selves in learning through the notion of digitised identity (to be elaborated below) may be conducive to foreign language acquisition. In addition to self-simulated learning, this discussion examines the digitization of online expressivity as a useful pedagogy concept in asynchronous Malay language pedagogy.

Distancing its standpoint from a bipolar real-emergent selfhood, this discussion adopts the notion of digitised self, which has its origins in J-pop. Digitised self is an offshoot stemming from the cultural logic of immaterial self (Allison, 2008). The Pokémon phenomenon offers significant evidence of immaterial self that inhabits the hearts of millions. The extensive fandom of Pokémon spawns a mix-media business of hand-held computer games, comic book, handbook, movie, soundtrack album, television animation series, trading cards, stickers, soft toys, clothes, posters, bed linen, wallpaper, mouse pads, key rings, and other merchandise worth billions of dollars (Buckingham \& Selfton-Green, 2004). Arguably, immaterial self is the reason behind the success of these small and cute merchandises, thus the flourishing of a digitised economy. There are two perspectives to the globalization of Pokémon. From the social cultural viewpoint, Pokémon as a digitised universe rather than a single product capitalizes on cuteness (kawaii), flexibility, and 
multi-dimentionality that appeal to the young adults (Allison, 2004). The manufacturers of bean bag-type soft toys will stop at no permutation of cuteness to part parents from their money, and confirm little girls in their addiction to collectable soft toys (cf. Grugeon, 2004, p. 79).

From a pedagogical viewpoint, on the other hand, the narratives in Pokémon invite practitioners to meaningful and pleasurable activities of collecting and competing as much as nurturing and cooperating (Buckingham \& Selfton-Green, 2004). If foreign language pedagogy includes what the learners might do by themselves, and in their own right, much language learning online is feasible with scripting and decorative activities afforded by a weblog (Sew, 2009, 2017a). In a recent study on the use of digitised comics in Hindi pedagogy, Peter Friedlander (2018) contemplates on the clicking, selecting or touching on screen elements to hear sounds as possible factors that contribute to active learning of the language. It is worthwhile to investigate if the digitised identity underlined by online expressivity may facilitate foreign language acquisition. In a recent study on new literacies of a person by the surname of Lee, a Chinese immigrant in USA, Lam (2006, p. 21) reports that:

...he was able to fashion himself as part of a global economy of semiotic workers whose productive labor or engagement with "texts" involves thinking creatively, setting goals and plans, gauging cultural trends, seeking out collaboration and teamwork, and pursuing self-initiated, just-in-time learning. Such a literacy portfolio stands in contrast with a schooling culture of standardized curriculum and well-defined tasks that are handed down to students.

As a caveat, the digitised interest of learners, and fans might be inconsistent. Elizabeth Grugeon (2004) reports that the Pokémon phenomenon in United Kingdom (UK) surged in 2000 but began to wane in 2001 with the arrival of Harry Potter, Beanie Babies, World Wrestling Federation, among others. That the Pokémon phenomenon is diminishing with the closing of Pokemon Center in 2005 after its New York debut in 2001, thus, reflects the fickle nature of the immaterial self (Raichu, 2008, p. 526). Interestingly, Project Runway's catch phrase, one day you are in the next day you are out is an apt reference to the unpredictable fashion interest of the young adults. The whimsical situation is similar with the digitised fascinations of an immaterial self. This discussion concedes that no single pedagogical strategy may lay claim to be the ultimate trend in foreign language pedagogy for good.

For example, the learning experience of the producing Japanese video project suggests that foreign language learning interest is fickle and constantly morphing. As a coordinator of video group in the intensive summer program of Japanese language and culture at Kobe University, Richard Harrison reports on learning inconsistency among different groups of 40 participants. While the Japanese language video project is a success, foreign students, and teaching assistants who were involved in the project, however, have expressed conflicting views on the video production based on the format of a Japanese television program. The matrix of mediation includes first, and foreign language competencies, genre format as learning content as well as technological variations amongst the learners, and between the learners, and the teaching assistants (Harrison, 2010, see Kitai \& Chan, 2015 for another positive Japanese language learning experience involving the use of videos). 
This discussion claims that the inconsistency of online expressivity does not hinder the output of online expressivity. Online expressivity may become saliently significant if the instructions encase language learning with happiness. In other words, striking a pact between learning and feeling happy is the order of the day in foreign language education. Happiness has a far-reaching effect on learning and economics. Joergen Oerstroem Moeller (2008) explicates that relevant social policy generates Danish economic growth because the social happiness resulted from appropriate social policies is critical for creativity at the individual, and the national level. Acknowledging the relevance of positive psychology in language acquisition, narrative study of selfperceived experience offers insights to successful language learning outcomes (cf. Oxford, Acuña, Hernández \& Smith, 2015). The tactile aspect of expressivity may contribute to active language learning. The positive feelings in Hindi language learners manoeuvring digitised comics may be a logical explanation for the inclination towards digitised comics in learning Hindi (Friedlander, 2018). Along the digital landscape of language pedagogy, learning Malay by means of a weblog, which is a digitised platform of Web 2.0, involves a semiotic exchange of symbolic transaction (Mortensen, 2008). This study offers an analysis of the symbolic transactions that appeal to the language learners in the formation of digitised identity while blogging a foreign language.

\section{Blogging Malay}

In the current Internet-oriented learning environment, the print material is losing its grip in the foreign language classroom due to the advent and influence of multimedia literacies generated by Web 2.0 (Lankshear \& Knobel, 2006). Computer-mediated experiences and digitised activities have transformed language learning into a multimodal collaborative activity. From his observation of young Chinese learners at the complementary schools in United Kingdom (UK), Li Wei informs that the informal use of digital devices has become commonplace in the classroom:

...almost all of the pupils have mobile phones and many bring computer games and other gadgets with them. They often text each other in class while listening to what the teacher has to say. They also communicate with others outside the school while following the class. Although most of them text message in English, many have Chinese input functions in their mobile phones and many of the computer games are in Chinese... The complex system of sound, vision, gesture, and digital and electronic signs and signals provides a multimodal learning environment, in which knowledge of the different languages, including the writing systems, are put to use.

$$
\text { (Li, 2011, p. 381) }
$$

In another study, the expert teacher trainer informs that the teacher training effort in United Kingdom (UK) serves as a timely reminder to language teachers (Grugeon, 2004, p. 87):

The evidence that the trainees collected from the children on the playground gave them insight into the pervasive influence of new technologies in their pupils' lives and the extent of their engagement with popular culture. Their analysis of their data will act as a springboard for their own understanding of the extent to which..." multiliteracies" needed to function in the modern, media-saturated world. 
Smarter than before, young children are creative with and sensitive to current affairs such as Iraq invasion. In 2003, UK children's stylized game yielded expressions from one group that suggested safety for babies at shelter as the male spouses has gone to war while another group of boys and girls were imagining themselves falling from airplanes in their games (Grugeon, 2004, p. 85).

Exploiting the potentials of digital learning and creative imagination, the discussion opines that engaging the Malay learners toward a happy and meaningful blogging experience would be an intelligent way to arrive at an effective-productive pedagogy. More importantly, the semiotics of expressivity online defined as the symbolic presentation of a digitised identity is worthy of our attention in designing foreign language pedagogy. This discussion is aware of the scepticism that the weblog's overall potential may be an ancillary experience in the end. Against the sceptical view, Jay L. Lemke (2004) explicates that learning is an incremental multimodal intelligent experience beyond textual interpretation. Further, Eva Lam $(2000,2004)$ observes that the design of learning environment in which the subjects of her study use to establish online interaction in a chatroom has accorded the learners with convincing voice for negotiation and interaction.

This discussion suggests that a balance between the use of online tools and freedom for manoeuvring digital expressivity online is a worthwhile pedagogical effort. Apart from a final written assessment worth $60 \%$, there is a $40 \%$ formative measurement on intermediate language ability for Malay modules offered at the Center for Language Studies (CLS), Faculty of Arts and Social Sciences, National University of Singapore (NUS). The course description of a secondlevel Malay module is outlined below for further discussion:
A. Digitised Project $10 \%$
B. Class Participation 10\%.
C. On-line assessment $20 \%$
D. Group Oral Presentation 20\%

Blogging has become the digitised project of the Malay module. The weblog provides considerable digitised support to portfolio-based assessment at the tertiary level (Burgess, 2006). A quarter of the $40 \%$ goes to the digitised project for Component $\mathrm{A}$ in the Malay as foreign language module. The digitised project contributes $10 \%$ to the final assessment, which consists of 20 marks in the assessment that has the breakdown outlined in Table 1 (cf. Sew, 2017b). Blogging in the Malay project supports measurable language learning in terms of vocabulary acquisition, grammatical constructions, sentence comprehension and digitised presentation skills.

In the current COVID-19 environment, Component A of the Malay module offers a relevant and useful learning avenue to the Malay language learners at NUS as they blog the language learning from a safe distance. The criteria for blogging Malay include the customized component of online expressivity in foreign language learning. In digitised literacy terms, Component A is an expression of multimodality online in which the language learners translate meanings from one modality to another. Weblog is relevant to tertiary education as it offers a simulation of networked learning to practice reinterpretation and re-contextualization of information across different media (cf. Lemke, 2004). In terms of peer-to-peer interaction as well as teacher-to-learner consultation, the foreign language blog becomes a social learning platform for exchanging ideas, discussing issues, 
rectifying misconceptions, and developing language rules and cultural information throughout the Malay language pedagogy (Sew, 2009).

Table 1: Criteria of blogging in Malay as a foreign language

\begin{tabular}{|l|l|c|}
\hline \multicolumn{1}{|c|}{ Criterion } & \multicolumn{1}{|c|}{ Remark } & Mark \\
\hline Basic Blog Entry & Malay language learners blog the selected tutorial questions for blogging. & 5 \\
\hline $\begin{array}{l}\text { Basic Grammatical } \\
\text { Correction }\end{array}$ & $\begin{array}{l}\text { Spelling and grammatical errors arising from the basic blog entries } \\
\text { highlighted to learners are accorded with the corrective strike-off function } \\
\text { in the learning process. }\end{array}$ & 5 \\
\hline New Blog Entry & $\begin{array}{l}\text { Malay language learners add new blog entries pertaining to their daily life } \\
\text { appropriate for public sharing. The marks are awarded based on linguistic } \\
\text { expressions including vocabulary reflective of creative language use. }\end{array}$ & 5 \\
\hline $\begin{array}{l}\text { New Grammatical } \\
\text { Correction }\end{array}$ & $\begin{array}{l}\text { Correction to the errors highlighted in the entries. Additional marks are } \\
\text { awarded to correction on affixation-related mistakes in lexical coinage, as it } \\
\text { is indicative of progressive learning of Malay. }\end{array}$ & 5 \\
\hline
\end{tabular}

\section{Digitizing expressivity}

Initiating Malay blogging, the learners are required to blog their answers for tutorial questions in weeks $3,4,5,6,7,8$ of the module. The tutorial questions range from blogging about the pet's name in three phrases, create a paragraph of four sentences with Malay conjunctions to identify the word classes in a prescribed text. These are guided questions based on the lecture and reading assignments. The digital training serves as progressive language foundation for the learners to blog more Malay entries of personal interest. The overall content of nine weblogs yields encouraging digital output, which divides further into different semiotic types as outlined in Table 2 (Sew, 2017b).

Table 2: Details of nine weblogs in Malay as a foreign language

\begin{tabular}{|l|l|c|c|c|c|}
\hline Weblog URL & Sex & Entry & $\begin{array}{l}\text { Digitised } \\
\text { Photo }\end{array}$ & $\begin{array}{l}\text { V i d e o } \\
\text { Clip }\end{array}$ & $\begin{array}{l}\text { C o m i c } \\
\text { Strip }\end{array}$ \\
\hline http://yongcw.wordpress.com/ & $\mathrm{M}$ & 18 & 12 & 0 & 1 \\
\hline http://chunghan.wordpress.com/ & $\mathrm{M}$ & 15 & 0 & 0 & 0 \\
\hline http://beritaerina.wordpress.com/ & $\mathrm{F}$ & 18 & 12 & 0 & 0 \\
\hline http://ibatiba.wordpress.com/ & $\mathrm{F}$ & 15 & 24 & 3 & 2 \\
\hline http://shuenlovesmalay.wordpress.com/ & $\mathrm{F}$ & 15 & 18 & 3 & 0 \\
\hline http://cantikduniasaya.wordpress.com/ & $\mathrm{F}$ & 17 & 20 & 0 & 0 \\
\hline http://cantikduniasaya.wordpress.com/ & $\mathrm{M}$ & 12 & 0 & 0 & 0 \\
\hline http://anniebagaimana.wordpress.com/ & $\mathrm{F}$ & 15 & 10 & 1 & 1 \\
\hline http://majulahmelayu.wordpress.com/ & $\mathrm{M}$ & 12 & 3 & 0 & 18 \\
\hline
\end{tabular}

Studying the Malay entries of the nine weblogs closely yields relevant pointers to the semiotics of performing Malay in the forms of online expressivity. The findings derived from blogging Malay among the tertiary learners across academic disciplines are useful to understand digitised behaviours indicative of an immaterial self. As part of the learning behaviours online, the respective personal entries, which are blogged independently by the learners outside of their 
Malay contact time, may account for the emergence of their digitised identities in foreign language learning. The outline below follows the order of the nine weblogs listed in Table 2. The English transliteration of these Malay entries are as follows (Sew, 2017b, p. 120-123).

Table 3: Digitised identity displays in Malay blog entries

\begin{tabular}{|c|c|c|}
\hline Initiated entries as personal interest in Weblog 1 & Media Support & Major/Gender \\
\hline Class party & 2 digitised photos & Engineering/Male \\
\hline Moon cake festival celebration & 2 digitised photos & \\
\hline Grey's anatomy & 2 digitised photos & \\
\hline Personal reflection on online test & - & \\
\hline Close friends & - & \\
\hline Recession woe & 1 comic strip & \\
\hline Reflection on a changed attitude against blogging & 1 digitised photo & \\
\hline Initiated entries as personal interest in Weblog 2 & & Engineering/Male \\
\hline My happy day & - & \\
\hline Forced to blog & 1 sad emoticon & \\
\hline My happy day Part 2 & - & \\
\hline My oral presentation & - & \\
\hline The long awaited rain & - & \\
\hline Reflection on a changed attitude against blogging & - & \\
\hline Initiated entries as personal interest in Weblog 3 & & $\begin{array}{l}\text { Mathematics/ } \\
\text { Female }\end{array}$ \\
\hline Beijing Olympics 2008 & 1 digitised photo & \\
\hline Elephant takes drug & 1 digitised photo & \\
\hline Fare hike & 2 digitised photos & \\
\hline The round moon & 2 digitised photos & \\
\hline Advertisement (NUS Band Performance) & 1 digitised picture & \\
\hline Economic downturn & - & \\
\hline Priority seat & 1 digitised picture & \\
\hline Post-performance celebration & 3 digitised photos & \\
\hline Initiated entries as personal interest in Weblog 4 & & $\begin{array}{ll}\text { Comm. \& New } \\
\text { Media/Female }\end{array}$ \\
\hline Hungry & 1 digitised picture & \\
\hline My beloved (a pet) & 1 digitised photo & \\
\hline Hari Raya and why I was late & $\begin{array}{l}13 \text { digitised } \\
\text { photos, } 1 \text { video } \\
\text { clip }\end{array}$ & \\
\hline Thumbtanic & 2 video clip & \\
\hline Love between human and robot? & 1 digitised picture & \\
\hline A recalcitrant 89 year-old woman & - & \\
\hline
\end{tabular}




\begin{tabular}{|c|c|c|}
\hline Accident & - & \\
\hline Initiated entries as personal interest in Weblog 5 & & Life Sciences/Female \\
\hline Self-introduction & $\begin{array}{l}\text { Video clip } \\
\text { of piano } \\
\text { performance }\end{array}$ & \\
\hline A present for my friend & $\begin{array}{l}9 \text { digitised photos } \\
\text { with caption }\end{array}$ & \\
\hline Wall-E (a movie review) & $\begin{array}{l}\text { Video clip of the } \\
\text { movie }\end{array}$ & \\
\hline A talented singer & $\begin{array}{l}\text { Video clip of the } \\
\text { singer }\end{array}$ & \\
\hline My favorite food & 1 digitised photo & \\
\hline Initiated entries as Personal interest in Weblog 6 & & $\begin{array}{l}\text { Social Sciences/ } \\
\text { Female }\end{array}$ \\
\hline Thank God It's Thursday & 1 digitised photo & \\
\hline My favorite: Fireworks & 2 digitised photos & \\
\hline My beloved children & 3 digitised photos & \\
\hline South Africa & 6 digitised photos & \\
\hline Sadness & - & \\
\hline To my father with respect & 2 digitised photos & \\
\hline Kanyed-West & 1 digitised photo & \\
\hline Initiated entries as Personal interest in Weblog 7 & & Engineering/Male \\
\hline Shapes & - & \\
\hline Stress & - & \\
\hline Reflection on blogging & - & \\
\hline Soccer competition tomorrow & - & \\
\hline Initiated entries as personal interest in Weblog 8 & & Mathematics/Female \\
\hline Today & $\begin{array}{l}1 \text { animated } \\
\text { digitised photo }\end{array}$ & \\
\hline My favorite TV program & 1 digitised photo & \\
\hline I want to be... & - & \\
\hline Whenever I am free & $\begin{array}{l}\text { I video clip, } 2 \\
\text { digitised photos }\end{array}$ & \\
\hline Very expensive & 2 digitised photos & \\
\hline Birthday party & 1 digitised photo & \\
\hline Initiated entries as Personal interest in Weblog 9 & & Social Sciences/Male \\
\hline My first post & - & \\
\hline Last Saturday and Sunday & - & \\
\hline
\end{tabular}




\begin{tabular}{|l|l|l|}
\hline Teenage mutant Ninja turtle & $\begin{array}{l}9 \text { original } \\
\text { digitised comic } \\
\text { strips }\end{array}$ & $\begin{array}{l}9 \text { edited digitised } \\
\text { comic strips }\end{array}$ \\
\hline
\end{tabular}

The analysis of the personal blog entries in Table 3 shows a divide between conventional, and new literacies emerges. Two of the nine weblogs represent conventional literacies with text entries as the only input, whereas the other seven weblogs illustrate a combination of multiliteracies with the inclusion of video clips, digitised photos, and comic strips. The non-linguistic modalities complement texted words in the production messages. At first blush, the nine weblogs seem to illustrate a gender-related variation in approaching personal blog entries with two conventional weblogs belonging to the male learner-bloggers. If we frame gender differences in terms of multiliteracies, two of the four male learner-bloggers $(50 \%)$ do not customize their entries with additional digitised media compared to all five female learner-bloggers (100\%), who have included digitised media in their personal blog entries generously. Based on the content in Table 2, all the four male bloggers $(100 \%)$ had not used video clip compared to the three female bloggers $(60 \%)$, who included video clips to elaborate the content of their personal blog entries.

The learners have not been given any instructions to answer any survey or participate in any face-to-face interview. This prevents any sense of coercion on the learners' part into e-learning project participation beyond the requirement of Component A as a subtype of assessment. After the completion of the module, all learners received an email at the end of the term seeking voluntary feedback on the use of weblog as the learning platform. Due to the obligation-free environment, only a female learner responded with further suggestions to exploit weblog in digitised pedagogy. The study examines the final blog entries of all the selected learners for any sign of blogging enthusiasm, or dissatisfaction as the possibility. Two male bloggers reflected positively in their final entries of blogging, but a third male learner informed explicitly in his blog that he has not acquired Malay literacy through blogging. When requested for a suggestion in lieu of weblog, the learner has kept his silence. Gender complex in online interactivity involves layers of relationships that interact dynamically between online and offline environments (Marshall, 2008, p. 507; see also the male demands of female avatars in online game in Corneliussen \& Mortensen, 2005).

Nevertheless, the male learners engage in blogging towards language acquisition in an equally productive fashion comparable with the female counterparts in digitised pedagogy as indicated by the number of entries in Table 2. The same may not be true for the digitised customization based on the breakdown in Table 3. According to Larissa Hjorth, the effort to enhance the use of online platform, or socio-emotive customization remains less popular among male learner-blogger. The customization of blog entries may be due to one's inclination for cute characters, which allow users to translate emotion into faces, and forge continuity between online and offline identity (Hjorth, 2008, p. 207-213). It is logical to investigate if the male learners would be placed in a disadvantaged pedagogy environment if they were required to customize blog entries in foreign language learning for future investigation. Suffice it to say here that digitised customization of blog entries should not be included as part of the project assessment criteria for the time being. The discussion tracks collective immaterial self in online expressivity in the next section. 


\section{Immaterial Self}

According to Wang Qiuyun, who studies online learning, there are four types of interactivity within a technology-based interactive learning environment. The techno-related interactivities comprise of learner-content, learner-instructor, learner-learner, and learner-interface (Wang 2008, p. 414). This discussion suggests that the learner-content component could include the subliminal space of learners' attentional choreography (Jones, 2004). Learners' attentional choreography unpacks the immaterial self, consisting of intra- and interpersonal intelligences. The immaterial self develops from mediating learning, and social activities both digitally, and interpersonally. Coordinating one's focus in attending to the real, and virtual worlds encompasses a series of in sync, or otherwise, activities from different communicators. Through such on- and offline sharing of inter-subjectivities, a language learner expresses the immaterial self whenever he or she engages in expressing one's digitised identity online.

Furthermore, digitised customization is the user's self-mediation within, and between online/offline identity and sociality (Hjorth, 2008). Performing digitised customization of personal blog entries becomes a pointer to the immaterial self behind Malay digitised expressivity:

... in the Asia Pacific region the cute is all-pervasive and yet disjunctive in its meaning. The use of cute capital (that is, cute characters) has long been viewed as a popular mode for both young and old to domesticate new technologies... by investigating customization techniques as indicative of the socio-cultural context, we can gain insight into the relationship between online and offline and attendant localized notions of individualism, community and social capital.

$$
\text { (Hjorth, 2008, p. 207-208) }
$$

This discussion scrutinizes the personal blog entries for digitised traces that may define a community of young Malay learners at tertiary level in Singapore. Two caveats are in place. Firstly, the online foreign language learning community is not an imaginary homogeneous group as even a cohort of 10 Malay learners-bloggers turns out to be highly heterogeneous in online expressivity. Secondly, the study rejects the gender bias claim that the female students tend to prefer blogging in this discussion of digitised customization. Although it is tempting to assume the data in Table 2, and Table 3 demonstrating a female-bias tendency in socio-emotive customization, however, the number in this discussion is insignificant. Based on video content analysis, it has been argued that identity is not an a priori state (Sew, 2015a), thus the formation of a digitised identity crosscuts the gender divide. Generally speaking, customization is well received by both sexes in language learning, and any gender bias claim is of little validity in this study, not least the context-sensitive factors may be significant in one instance but muted in another as illustrated in several genderrelated analyses (Cameron, 2007, 2009).

In blogging Malay after the formal curriculum schedule, the element of fun that appeals to one's immaterial self is critical to ensure the smooth flow of blogging in a foreign language. Incorporating cute aesthetics from digitised entertainment into language pedagogy is conducive for blogging Malay, not least because the participants in this type of asynchronous learning are undergoing dreadful isolation to forge communication online: 
...in times of change, leaving old roles, seeking change, and forming new relationships, time spent with media...must be at the cost of face-to-face interactions...mediated communication is by its nature isolating. Our lives are full of mediated experiences at the cost of face-to-face relations... Mediated communication, regardless of richness, cannot approach the inherent interactivity of face-to-face communication.

(Cutler, 1996, p. 328)

When interaction is reverted to multimodal symbolic exchanges online, the digitised identity of Malay learners naturally requires more than words to attract and sustain the attention of audience online (Sew, 2012). Digitised identity may be considered as interactional competence in second language pragmatics. The participatory framework, and modes of meaning in the framework of interactional competence (Young, 2019) offer a collective basis for the emergence of a digitised identity in the blogging learners. This discussion conjectures that exploiting the weblog to learn a language and deploying multimodal resources to express oneself in a foreign language have inadvertently led to an expression of digitised identity among the Malay language learners.

Appealing to positive psychology, the cute capital that glorifies the face of online expressivity becomes a universal appeal among the young adults. The notion of interactionally-emergent identity (Ishihara, 2019) is useful to describe the digitised identity of the tertiary Malay language learners in question. What might have been a faceless online expressivity of Malay language learning would transform digitally using multimodal content in the forms of digital photos, video clips and online comic strips. Although all the male learners-bloggers like to face-design their blogging, a digitised environment of language learning may be motivating the learners to present their blog entries in customized fashion. This notion of blogging as a semiotic performance of face-design is noticeable in many of the personal entries containing digitised content as outlined in Table 3. Learners of Malay as a foreign language are inclined to blog their own referential meanings with additional media content as part of their digitised identity. Although these digitised supplements are non-linguistic content, the content is communicative, nonetheless, representing a series of multi-sensory pragmatics in Malay language education produced asynchronously.

Reminding that the ways in which the digitised complements operate are crucial to media study, John Potts (2008) cautions against the misconception of accepting technologies as deterministic tool. This study is aligned with the notion that human behaviour online is concerned with the human exchange of symbols online (Mortensen, 2008). The use of emoticons and symbols in the Facebook posts of young Malays between 13 to 21 years old, for example, is rather extensive and significant in conveying emotive meanings (Nor Fazilah Noor Din \& Hishamudin Isam, 2019). Indirectly, this affirms that digitised identity exists, thus, it is up to the language instructors to incorporate the digitised persona whenever online language pedagogy is deployed. Understandably, then, Claire Kramsch (2014) includes the use of emoticons in everyday communication as part of foreign language teaching in the era of globalization.

This discussion concedes that the learners' dexterity with technologies would have an impact on the presentation of immaterial self. In manipulating the blog entries, a learner of Malay leaves behind the imprints of a more refined interdependent immaterial self, which will be elaborated below. The versatility of the Malay language bloggers in exploiting semiotic 
affordances to construct representations of immaterial self is contingent on their technological aptitude. Animation and impersonation may become the common formats in the construction of digitised identity online. In any case, the user's manipulation of online texts, and digitised support involves literacies tied to knowing how to use the internet within intense interaction with other forms of identity and enablement of identity (Durán, 2008, p. 1236). This discussion reconsiders Malay as a lingua franca in the cyber-world. If the real-world Malay lingua franca comprises widely spoken varieties including Bazaar Malay of the wet market (Bao \& Khin, 2010), online Malay widely shared by the netizens with a digitised identity will not be exclusively linguistic devoid of online expressivity. An online lingua franca Malay consisting of animation, colours, emoticons, hybridity, iconic signs, letters, sounds, words, visual imageries, etc. is the semiotic norm of online interaction.

\section{Interdependent-self online}

Learners' participation in online activities is partially motivated by the possibility of rekindling and exchanging immaterial self with another person either synchronously, or asynchronously. The immaterial self is the underlining persona in the digitised identity of a learner when he or she is engaging in online expressivity. Lam (2000, p. 459) suggests that learner constructs their identities through the selective appropriation of literacy resources. Along this vein, online identity of Malay language learners is a discursive multimodal construct assisted with technology. In the emergence of digitised identity, the young adult learners may exhibit a welcome engagement with the cute capital. English children in UK, and Chinese immigrants in USA, for example, engage themselves in Japanese popular culture, e.g. Pokémon and the popular celebrities. In comparison, the tertiary foreign language learners in Singapore are attracted to the Cantonese, Korean, Malay, Singapore, and Mandarin pop cultures, selectively.

The Malay blogging of tertiary learners in Singapore displays online expressivity in the form of anecdotal information, such as digitised photos, video clips and comic strips. The blogging composition from learners of different academic majors contain a collective digitised identity reflective of their interdependent self. Indicatively, the interdependent self is observed in the topics of blogging that exhibit group importance online. This is noticeable from all the nine Asian bloggers with at least one entry concerning group reliance in each blog. The content in Table 3 is reorganized further into topics that point to the existence of interdependent self as expressed by foreign language learners. Samples of blog entries that reflect digitised identity characterizing Malay language learning online are highlighted in Table 4.

Table 4: Signs of interdependent immaterial self in Malay blog entries

\begin{tabular}{|l|l|}
\hline \multicolumn{1}{|c|}{ Blogging Malay } & Entries of interdependent immaterial self \\
\hline Weblog 1 Engineering & $\begin{array}{l}\text { Moon cake festival celebration with 2 digitised photo } \\
\text { Close Friends }\end{array}$ \\
\hline Weblog 2 Engineering & Reflection on a changed attitude against blogging \\
\hline
\end{tabular}

e ISSN 2735 - 1904

https://doi.org/10.22452/JOMAS.vol31no1.9 


\begin{tabular}{|l|l|}
\hline Weblog 3 Mathematics & $\begin{array}{l}\text { Beijing Olympics 2008 with digitised photo } \\
\text { Priority Seat with 1 digitised picture }\end{array}$ \\
\hline $\begin{array}{l}\text { Weblog 4 Communication \& New } \\
\text { Media }\end{array}$ & $\begin{array}{l}\text { Hari Raya and Why I was late with 13 digitised photos and 1 video } \\
\text { clip }\end{array}$ \\
\hline Weblog 5 Life Sciences & A present for my friend with 9 digitised photos \\
\hline Weblog 6 Social Sciences & $\begin{array}{l}\text { My beloved children with 3 digitised photos } \\
\text { To my father with respect with 2 digitised photos }\end{array}$ \\
\hline Weblog 7 Engineering & Soccer Competition Tomorrow \\
\hline Weblog 8 Mathematics & $\begin{array}{l}\text { Whenever I am free... } \\
\text { Birthday Party }\end{array}$ \\
\hline Weblog 9 Social Sciences & Last Saturday and Sunday \\
\hline
\end{tabular}

Expressing online while learning Malay as a foreign language is a self-centred narrative production containing utterances of one's immaterial self. As Richard P. Durán informs that:

...the dramaturgical projection of identity is central to all forms of literacy as meaning and sense making, and that those notions of identity projection and sense making are not just about communicating in language. They abound electronically in creating and navigating the images and media inscribed in Internet social Web sites.

(Durán, 2008, p. 1238)

Accordingly, online expressivity requires an intelligent appropriation of multisemiotic literacy, which involves the skills to produce meaning for communicative, displaying, emotive, and identifying purposes (cf. Sew, 2010a). The initiative to present the traditional Malay art of Bangsawan in 2-D animation format demonstrates the online intelligence of producing multimodal online expressivity that aligns traditional performing arts with the current mode of consumption (cf. Nur Yuhanis Mohd. Nasir \& Rahmah Bujang, 2013).

Acknowledging David Block's concern (2002) on the standardized practice of second language acquisition, this study points to the significance of exploiting online expressivity as a conducive e-learning format in the pedagogy of foreign language. If we accept that online expressivity gives rise to digitised identity, we could allow the language learners manipulating multimodal resources for expressing themselves with the language (content) online. The notion of digitised identity underscored by online expressivity is an overdue pedagogical concept in the online foreign language learning environment. Foreign language pedagogy studies conducted in Singapore suggest that online expressivity is relevant to mobile-based pedagogy (Shigeta \& Chao, 2018), and blog-based pedagogy (Sew, 2015b, 2017a). This discussion conjectures that incorporating digitised identity into the design of online language pedagogy may promote Malay, the seventh most spoken language in the world (Awang Azman Awang Pawi, 2009), not least because the enhanced pedagogy will maintain a sizable following of foreign language learners.

\section{Just-in-time intervention as discussion}

This study excludes one weblog of Malay that requires further explanation. Nothing was found in the weblog set up by a final year Mathematics-major. This Malay language learner, who had 
blogged a reasonable amount of entries with digitised photos both original, and imported resources, has since removed all the digital content immediately after the completion of his foreign language learning. In a one-to-one discussion with the special learner, the male blogger shared his intention to blog after accumulating all the necessary materials at the end of the term. This discussion reports that foreign language blogging may take to the repository approach. The current academic pattern normally sees the undergraduate learning stress ballooning at the end of the term with assignments and tests, at times, spilling into the reading week prior to the examination proper. Reading week is supposed to be devoid of formal teaching as it is specifically created for study prior to the final written examination. This discussion notes that personal decision-making is a factor that determines if a digitised identity may develop from blogging foreign language learning.

Blogging remains a skill-based endeavour that requires password access, technical manoeuvring of written content, selection of visuals, recording of video clips, all of which involves a notional and meticulous organization of data. Such effort is difficult to accomplish if the asynchronous interactivity is postponed to the end of the academic term. Furthermore, haphazard blogging defeats the purpose of progressive learning and deny the learner the opportunities of receiving external comments, hence removing the reflective advantage from the process of blogging. When blogging Malay literacy becomes the last-minute practice, it is a degenerate form of digitised pedagogy. For the record, the learner was an avid computer game player who has maintained a commercial account for online games. Indeed, the digital behaviour of language learners inside the classroom may be a total opposite of that outside the classroom (Sew, 2010b).

Just-In-Time support (Boettcher, 2008) to assist drifting bloggers should be available in foreign language blogging. In managing irregular blogging, the instructor may broach on the adverse consequences of last-minute blogging casually through a chat prior to a tutorial lesson proper. A second remedial chat may transpire on how the learner could structure time and capitalize on short-term memory in learning by blogging immediately within 24 hours. In our case of irregular blogging, the practice took shape with basic entries from tutorial discussions and a picture of the pet dog from his father. The learner expressed appreciation for the persuasive measure after noticing that the projects and tests of other modules remained incomplete in the final weeks of the semester. Dutiful blogging may be a challenge to some learners, as it taps on personal creativity when there was no semiotic-interactive scaffold to develop learning.

During blogging, a learner has come across a Malay storybook written for children online and has begun blogging part of the story as his project in a separate Malay module. Words that attracted his attention were translated into English. This was his approach of developing vocabulary in Malay. Signs of learning satisfaction could be traced to the photos inserted to elaborate each entry of 20 to 30 words. The literacy blogging made use of 50\% of the children's story book in three weeks. In the evaluation, however, new creation has been relatively low compared to the other learners-bloggers of the cohort, who introduced original stories complete with digitised photographs as well as video clips. In the end, the book-based blogger was advised to remove all the content due to copyrights infringement issue, for which he happily adhered. 


\section{Concluding remarks}

The blogging preferences of tertiary language learners undertaking a Malay language module have provided valuable insights on digitised expressivity in learning a foreign language. There were motivating and demotivating factors encouraging or inhibiting expressivity online. Many learners were tempted to use digitised materials in acquiring and commanding foreign language. The notion of sharing a digitised face online could be further refined with the universal appeal to cuteness. Online expressivity as a form of learner's identity may be capitalized to motivate foreign language learning either asynchronously, or synchronously. It is noticeable that the topics of Malay blogging gravitated to themes pertaining to an interdependent self, as the content in the blog related to others as part of their co-existence. The interrelatedness proclivity suggests further that communal topics may spur digitised expressivity for foreign language learners of Asian origins.

Digitised foreign language pedagogy may face fickle learning interest that leads to unpredictable outcomes over time. Disinterested language learners might find blogging a chore and adopt a last-minute approach towards blogging literacy. Constant monitoring and timely interventions are important steps to remediate any inertia arising from the assumption that a blog is an online repository tool. The progressive use of language, and non-linguistic complements in blogging Malay, including the follow-up responses to the instructor's online comments, offer interested language practitioners the relevant information to design language pedagogy that appeals to positive psychology in the era of multimodal literacies. Consequently, a learner-centred online practice is a strength in foreign language education, not least a content-based approach may be overly reliant on a standard curriculum, least the happy opportunity of organizing, recalibrating and sharing expressions online is in neglect.

\section{References}

Allison, A. (2008, November 17). Virtual cartographies and techno-intimacy: Youth in millennial Japan. Seminar of Science, Technology \& Society Cluster, NUS.

Allison, A. (2004). Cuteness as Japan's millennial product. In J. Tobin (Ed.), The rise and fall of Pokémon (pp. 34-49). Durham, United States of America: Duke University Press.

Awang Azman Awang Pawi. (2009). Zeitgeist di cakera nusantara. Jurnal Pengajian Melayu/ Journal of Malay Studies (JOMAS), 20, 1-25.

Bao, Z., \& Aye, K. K. (2010). Bazaar Malay topics. Journal of Pidgin and Creole Languages, $25(1), 155-171$.

Block, D. (2002). 'McCommunication': A problem in the frame for SLA. In D. Block \& D. Cameron (Eds.), Globalization \& language teaching (pp. 117-133). London: Routledge.

Boettcher, V. J. (2008). Just-In-Time support: 8 best practices for providing the help online faculty need - When they need it. Campus Technology, 22(2), 26-29.

Buckingham, D., \& Sefton-Green, J. (2004). Structure, agency, and pedagogy in children's media culture. In J. Tobin (Ed.), The rise and fall of Pokémon, (pp. 12-33). Durham, USA: Duke University Press.

Burgess, J. (2006). Blogging to learn, learning to blog. In A. Bruns \& J. Jacobs (Eds.), Uses of blog 
(pp. 105-114). New York: Peter Lang.

Cameron, D. (2009). Sex/Gender, language and the new biologism. Applied Linguistics, 31(2), $173-192$

Cameron, D. (2007). The myth of Mars and Venus. New York: Oxford University Press.

Chang W. C., Osman, M. M., Tong, E. M. W., \& Tan, D. (2011). Self-construal and subjective wellbeing in two ethnic communities in Singapore. Psychology, 2(2), 63-70.

Coiro, J., Knobel, M., Lankshear, C., \& Leu, D. J. (Eds.) (2008). Handbook of research on new literacies. New York: Lawrence Erlbaum Associates.

Corneliussen, H. G., \& Mortensen, T. E. (2005, August 8-10). The non-sense of gender in neverwinter nights. Women in Games Conference, Dundee, Scotland. Retrieved from http:// tilsett.hivolda.no/tm/Neverwinter_Nights.pdf

Cutler, R. H. (1996). Technologies, relations, and selves. In L. Strate, R. Jacobson \& S. B. Gibson (Eds.), Communication and cyberspace: Social interaction in an electronic environment (pp. 317-333). Cresskill, New Jersey: Hampton Press.

Durán, R. P. (2008). A commentary on Lam (2000). In J. Coiro, M. Knobel, C. Lankshear, \& D. J. Leu (Eds.), Handbook of research on New Literacies (pp. 1229-1240). New York: Lawrence Erlbaum Associates.

Friedlander, P. (2018). Teaching Hindi with comics. Electronic Journal of Foreign Language Teaching, 15(Suppl. 1), 163-178. Retrieved from http://e-flt.nus.edu.sg/v15s12018/ friedlander.pdf.

Grugeon, E. (2004). From Pokémon to Potter: Trainee teachers explore children's media-related play, 2000-2003. In J. Goldstein, D. Buckingham \& G. Brougére (Eds.), Toys, games, and media (pp. 73-89). New Jersey: Lawrence Erlbaum Associates.

Harrison, R. (2010). Media and mediation: Teachers, learners, and learning environments. In W. M. Chan, K. N. Chin, M. Nagami \& T. Suthiwan (Eds.), Media in foreign language teaching and learning (pp. 297-311). Singapore: CLS, NUS.

Hjorth, L. (2008). Cybercute politics: The Internet cyworld and gender performativity in Korea. In Y. Kim (Ed.), Media consumption and everyday life in Asia (pp. 203-216). New York: Routledge.

Ishihara, N. (2019). Identitiy and agency in L2 pragmatics. In N. Taguchi (ed.), The Routledge handbook of second language acquisition and pragmatics (pp. 161-175). New York: Taylor \& Francis.

Kitai, S., \& Chan, W. M. (2015). Learning language and culture through video clips: An action research study. In W. C. Chan, S. Kumar, M. Nagami \& I. Walker (eds.), Culture and foreign language education: Insights from research and implications for the practice (pp. 299-330). Berlin: Mouton de Gruyter.

Kramsch, C. (2014). Teaching foreign languages in an era of globalization: Introduction. The Modern Language Journal, 98(1), 296-311.

Jones, R. H. (2004). The problem of context in computer-mediated communication. In P. Levine \& R. Scollon (Eds.), Discourse \& technology: Multimodal discourse analysis (pp. 20-33). Washington D.C.: Georgetown University Press.

Lam, W. S. E. (2000). L2 Literacy and the design of the self: A case study of a teenager writing on the Internet. TESOL Quarterly, 34(3), 457-482. 
Lam, W. S. E. (2004). Second language socialization in a bilingual chat room: Global and local considerations. Language Learning \& Technology, 8(3), 44-65.

Lam, W. S. E. (2006). Re-envisioning language, literacy, and the immigrant subject in new mediascapes. Pedagogies: An International Journal, 1(3), 171-195.

Lankshear, C, \& Knobel, M. (2006). New literacies: Everyday practices and classroom learning. Maidenhead, United Kingdom: Open University Press.

Lemke, J. L. (2004). Multiplying intelligences: Hypermedia and social semiotics. In J. L. Kincheloe (Ed.), Multiple Intelligences reconsidered (pp. 177-200). New York: Peter Lang.

Li, W. (2011). Multilinguality, multimodality, and multicompetence: Code- and modeswitching by minority ethnic children in complementary schools. The Modern Language Journal, 95(3), 370-384.

Marshall, J. P. (2008). Gender in online communication. In J. Coiro, M. Knobel, C. Lankshear, \& D. J. Leu (Eds.), Handbook of research on new literacies (pp. 491-519). New York: Lawrence Erlbaum Associates.

Moeller, J. O. (2008, November 20-21). Happiness as a driver for creativity and growth: The example of Denmark. Symposium on interdisciplinary studies on happiness, Orchard Parade Hotel, Singapore.

Mortensen, T. E. (2008). Of a divided mind: Weblog literacy. In J. Coiro, M. Knobel, C. Lankshear, \& D. J. Leu (Eds.), Handbook of research on new literacies (pp. 449-466). New York: Lawrence Erlbaum Associates.

Nor Fazilah Noor Din, \& Hishamudin Isam. (2019). Tema perbualan remaja Malaysia dalam Facebook. Jurnal Pengajian Melayu/Journal of Malay Studies (JOMAS), 30, 137-166.

Nur Yuhanis Mohd. Nasir, \& Rahmah Bujang. (2013). Animation research: Constructing Bangsawan in 2D format. Jurnal Pengajian Melayu/Journal of Malay Studies (JOMAS), 24, 248-271.

Oxford, R. L., Acuña, G. P., Hernández, M. S., \& Smith, A. L. (2015). "A language is a mentality": A narrative, positive-psychological view of six learners' development of bilingualism. System, 55, 100-110.

Potts, J. (2008). Who's afraid of technological determinism? Another look at medium theory. Fibreculture Journal Issue 12 - Models, Metamodels and Contemporary Media. Retrieved from http://journal.fibreculture.org/issue12/index.html.

Raichu 526. (2008). Pokemon center NY. Retrieved from http://www.pokezam.com/pokemon/ pokecenterny/.

Sawyer, R. K. (2001). Creating conversations: Improvisation in everyday discourse. New Jersey: Hampton Press.

Sew, J. W. (2017a). Learning Malay with poems: From understanding stylistics to blogging poetic expressions. Issues in Language Studies, 6(2), 45-64. Retrieved from http://publisher.unimas.my/ojs/index.php/ILS/article/view/1622.

Sew, J. W. (2017b). From face to screen: Interactive multimodal semiotics at work. Kota Samarahan, Sarawak: UNIMAS Press.

Sew, J.W. (2015a). Semiotics of performing in Najwa Latif's music videos. Malaysian Journal of Communication, 33(2), 299-321. Retrieved from http://ejournal.ukm.my/mjc/article/ view/14913. 
Sew, J.W. (2015b). Assessing Malay proficiency at tertiary level: Criteria features in learner language. Kajian Malaysia: Journal of Malaysian Studies, 33(1), 19-41. Retrieved from http:// web.usm.my $/ \mathrm{km} / 33(1) 2015 / \mathrm{km} 33012015$ _02.pdf.

Sew, J. W. (2012). Learning Malay online at tertiary level. GEMA: Online Journal of Language Studies, 12(1), 147-162. Retrieved from http://ejournal.ukm.my/gema/article/view/26.

Sew, J. W. (2010a).Persembahan@Media.com. Kuala Lumpur: Penerbit Universiti Malaya.

Sew, J. W. (2010b). [Essay review of the book, beyond technology: Children's learning in the age of digital culture by D. Buckingham]. Teaching and Teacher Education, 26(5), 1224-1225. Retrieved from https://www.sciencedirect.com/science/article/abs/pii/S0742051X09001681

Sew, J. W. (2009). Wired new learning: Blogging Malay literacy. Electronic Journal of Foreign Language Teaching, 6(Suppl. 1), 302-314. Retrieved from https://e-flt.nus.edu.sg/v6sp12009/ sew.pdf.

Shigeta, S., \& Chao, J. Y. (2018, December 6-8). Developing mobile learning Japanese language course. The Eight CLS International Language Conference, NUS.

Tobin, J. (Ed.) (2004). The rise and fall of Pokémon. Durham, United States of America: Duke University Press.

Wang, Q. (2008). A generic model for guiding the interaction of ICT into teaching and learning. Innovations in Education and Teaching International, 45(4), 411-419.

Young, R. F. (2019). Interactional competence and L2 pragmatics. In N. Taguchi (Ed.), The Routledge handbook of second language acquisition and pragmatics (pp 93-110). New York: Taylor \& Francis. 